\title{
HIV-related stigma and psychological distress: the harmful effects of specific stigma manifestations in various social settings
}

Citation for published version (APA):

Stutterheim, S., Pryor, J. B., Bos, A. E. R., Hoogendijk, R., Muris, P., \& Schaalma, H. P. (2009). HIVrelated stigma and psychological distress: the harmful effects of specific stigma manifestations in various social settings. Aids, 23(17), 2353-2357. https://doi.org/10.1097/QAD.0b013e3283320dce

Document status and date:

Published: 01/01/2009

DOI:

10.1097/QAD.0b013e3283320dce

Document Version:

Publisher's PDF, also known as Version of record

\section{Document license:}

Taverne

Please check the document version of this publication:

- A submitted manuscript is the version of the article upon submission and before peer-review. There can be important differences between the submitted version and the official published version of record.

People interested in the research are advised to contact the author for the final version of the publication, or visit the DOI to the publisher's website.

- The final author version and the galley proof are versions of the publication after peer review.

- The final published version features the final layout of the paper including the volume, issue and page numbers.

Link to publication

\footnotetext{
General rights rights.

- You may freely distribute the URL identifying the publication in the public portal. please follow below link for the End User Agreement:

www.umlib.nl/taverne-license

Take down policy

If you believe that this document breaches copyright please contact us at:

repository@maastrichtuniversity.nl

providing details and we will investigate your claim.
}

Copyright and moral rights for the publications made accessible in the public portal are retained by the authors and/or other copyright owners and it is a condition of accessing publications that users recognise and abide by the legal requirements associated with these

- Users may download and print one copy of any publication from the public portal for the purpose of private study or research.

- You may not further distribute the material or use it for any profit-making activity or commercial gain

If the publication is distributed under the terms of Article $25 \mathrm{fa}$ of the Dutch Copyright Act, indicated by the "Taverne" license above, 


\title{
HIV-related stigma and psychological distress: the harmful effects of specific stigma manifestations in various social settings
}

\author{
Sarah E. Stutterheim ${ }^{a}$, John B. Pryor ${ }^{b}$, Arjan E.R. Bos ${ }^{a}$, \\ Robert Hoogendijk ${ }^{c}$, Peter Muris ${ }^{c}$ and Herman P. Schaalma ${ }^{a, *}$
}

Objectives: Recent research has shown that experiences of stigmatization have an adverse impact on the psychological well being of people living with HIV/AIDS (PLWHA). Most studies investigating this relationship employ an aggregate measure of stigma. Although this approach provides useful information about the psychological implications of HIV-related stigma in general, it neglects to acknowledge the possibility that some manifestations in specific settings may be psychologically more detrimental than others. The present study examines which specific stigma experiences are most strongly related to psychological distress across a number of social settings.

Methods: A cross-sectional survey was administered to 667 PLWHA in the Netherlands. We examined participants' experiences of 11 manifestations of HIV-related stigma in six social settings. Linear regression analyses were conducted to determine which setting-specific manifestations best predict psychological distress after controlling for marital status, education and health status.

Results: Three manifestations in family settings, namely receiving advice to conceal one's status, being avoided and being treated with exaggerated kindness, and one manifestation in healthcare settings, namely awkward social interaction, best predicted psychological distress in PLWHA.

Conclusion: Manifestations of HIV-related stigma vary according to setting. Certain manifestations in specific social settings impact the psychological well being of PLWHA more than others. In this study, certain experiences of stigmatization with PLWHA's families and in healthcare settings were more strongly related to psychological distress than experiences occurring in other social settings. These findings suggest that stigma reduction interventions focusing on these influential settings may benefit the psychological well being of PLWHA. ๑ 2009 Wolters Kluwer Health | Lippincott Williams \& Wilkins

AIDS 2009, 23:2353-2357

Keywords: AIDS, HIV, mental health, stigma

${ }^{\mathrm{a}}$ Department of Work and Social Psychology, Maastricht University, Maastricht, The Netherlands, ${ }^{\mathrm{b}}$ Department of Psychology, Illinois State University, Normal, Illinois, USA, and ' Institute of Psychology, Erasmus University Rotterdam, Rotterdam, The Netherlands.

Correspondence to Sarah E. Stutterheim, Department of Work and Social Psychology, Maastricht University, 6200 MD Maastricht, The Netherlands.

Tel: +31 43 3881401; e-mail: s.stutterheim@psychology.unimaas.nl

* deceased.

Received: 24 April 2009; revised: 10 August 2009; accepted: 19 August 2009.

DOI:10.1097/QAD.0b013e3283320dce

ISSN 0269-9370 (c) 2009 Wolters Kluwer Health | Lippincott Williams \& Wilkins Copyright @ Lippincott Williams \& Wilkins. Unauthorized reproduction of this article is prohibited. 


\section{Introduction}

HIV-related stigma is a social phenomenon whereby a person is considered to possess a discrediting attribute and thus deemed tainted, spoiled or flawed by others [1-4]. HIV-related stigma can hamper HIV prevention efforts [5], inhibit treatment adherence [6-8], function as a barrier to HIV testing $[9,10]$ and negatively impact social relationships and the psychological well being of people living with HIV/AIDS (PLWHA) [11-14]. In fact, research conducted in various countries, including South Africa [15], China [16], Peru [17] and the USA [18-22], has demonstrated that HIV-related stigma independently contributes to psychological distress over and above health status and HIV-related symptoms.

Stigmatizing reactions to PLWHA manifest in a number of ways across a range of settings. Relevant manifestations include avoidance, exclusion, rejection, isolation, social ostracism, blaming, violence, service denial, physical distance, indifference, awkward social interaction and being advised to conceal one's status [7,22-32]. Relevant settings are families, communities, friends or acquaintances, sexual relationships, healthcare settings, the housing sector, the financial services sector, religious institutions, while travelling or migrating, work and educational settings $[7,15,24,26,27,29,32-37]$.

To our knowledge, no previous quantitative study has explored how particular manifestations in specific social settings impact the psychological well being of PLWHA. In fact, most studies investigating the psychological impact of HIV-related stigma employ an aggregate measure of stigma (e.g. HIV stigma scale [38] and AIDS-related stigma scale [39]). Although this approach provides useful information about the psychological implications of HIV-related stigma in general, it neglects to acknowledge the possibility that some manifestations in specific settings may be psychologically more detrimental than others. The present study examines which specific stigma experiences are most strongly related to psychological distress across a number of social settings.

\section{Methods}

\section{Participants and procedures}

All data were obtained from an anonymous national survey with PLWHA in the Netherlands. Participation was voluntary, informed consent was provided and no monetary compensation was involved. Following approval from Maastricht University's Ethics Committee, a total of 2264 surveys were distributed by the Dutch HIV Association $(n=1433)$ and by HIV nurses $(n=823)$. The surveys distributed by the HIV Association were sent by mail to all members in May 2007 with a reminder letter 4 weeks later. The surveys distributed by HIV nurses were handed out to patients during consultations between June and September 2007. A total of 669 participants completed the survey (response $=29.5 \%$ ). Of these, 468 were recruited by the HIV association (response $=32.7 \%$ ) and 193 by HIV nurses (response $=23.5 \%)$. Three participants contacted the researchers directly for a survey. For five other participants, data on how they were recruited was missing. Two surveys were excluded from the analyses because the corresponding participants were outliers with respect to age (6 and 97 years), thus yielding a total of 667 participants.

Of these $667,86.2 \%$ were men and $13.8 \%$ were women. Age ranged from 17 to 75 years with a mean age of 46.6 $(\mathrm{SD}=9.6)$ years. Almost half $(49.5 \%)$ had at least a Bachelor's degree, $31.0 \%$ had a high school diploma and some vocational training and $19.5 \%$ had a high school diploma or less. Furthermore, $68.3 \%$ had paid employment and $48.4 \%$ had a long-term partner. The majority defined themselves as gay (79.5\%), and from Europe or North America (90.6\%). Most participants (87.5\%) had acquired HIV through sexual intercourse. The mean time since diagnosis was $8.75(\mathrm{SD}=6.0)$ years.

\section{Measures}

\section{HIV-related stigma}

Stigma manifestations were measured using an index developed by the authors (available upon request) following a review of the social stigma literature and a focus group with experts, PLWHA and service providers working with various PLWHA populations in the Netherlands. This index measured 11 manifestations across six social settings. The manifestations were increased physical distance, awkward social interaction, indifference, avoidance, blaming, exaggerated kindness, aggression, exclusion, excessive hygienic measures, being told to disclose one's status and being told to conceal one's status. The settings were friends, family, partner, healthcare sector, work and leisure activities. The questions were formatted such that participants first indicated whether they had experienced a given manifestation. They then indicated the settings in which that manifestation occurred. Participants were permitted to mark more than one setting.

\section{Psychological distress}

Psychological distress was measured using a validated version of the Mental Health Inventory, which measures depression, anxiety, positive affect and behavioral control [40]. The scale comprises 18 items, all of which are answered on a six-point scale ranging from one (none of the time) to six (all of the time). A higher score is indicative of more psychological distress. Cronbach's $\alpha$ was 0.94 .

\section{Demographic and background characteristics}

Demographic characteristics measured included sex, age, educational attainment, employment, marital status, sexual orientation and ethnic background. Other background characteristics measured included the mode by which one 
acquired HIV, time since diagnosis, the presence of visible symptoms, current treatment with antiretroviral therapy, self-reported health status and recruitment method.

\section{Data analyses}

To determine whether settings differ with respect to the mean number of manifestations, a repeated measures analysis of variance and paired samples $t$-tests were conducted. For the $t$-tests, $P$ values less than 0.001 were considered statistically significant. This was followed by a series of setting-specific linear regressions of psychological distress on the 11 manifestations. Covariates were determined by initially establishing which demographic and background characteristics were correlated with psychological distress. All significant demographic and background characteristics were then entered into an initial linear regression model. Those that remained significant, namely having a partner, educational attainment and self-reported health status, were then included in the setting-specific regression analyses. Following these analyses, a final model was tested to determine which particular manifestation and setting combinations most strongly predicted psychological distress. This model included only those predictors that were significant in the setting-specific regression models. For all regression models, $P$ values less than 0.05 (two tailed) were considered statistically significant.

\section{Results}

Repeated measures analysis of variance established that the mean number of stigma manifestations differed significantly across settings $F(1,634)$ is equal to $46.749, P$ value is less than $0.001, \eta^{2}$ is equal to 0.07 . Paired samples $t$-tests showed the mean number of manifestations in the setting friends $(M=1.14, \mathrm{SD}=1.67)$ was not significantly higher than with family $(M=0.96, \mathrm{SD}=1.55)$ but was significantly higher than all other settings, all $t(634)$ s were greater than 4.11 and $P$ values were less than 0.001 . Also, the settings family, healthcare sector $(M=0.87, \mathrm{SD}=1.38)$ and work $(M=0.83, \mathrm{SD}=1.48)$, which did not differ significantly from one another, all had significantly higher means than the settings partner $(M=0.41, \mathrm{SD}=0.87)$ and leisure activities $(M=0.40, \mathrm{SD}=1.11)$, all $t(634)$ s were greater than 6.83 and $P$ values were less than 0.001 .

Six hierarchical linear regression analyses investigated the relationships between stigma experiences in each of the specific settings and psychological distress (Table 1). Significant predictors were: (1) for friends: blame, awkward social interaction and exaggerated kindness $(P<0.05)$; $(2)$ for family: being advised to conceal one's status, avoidance and exaggerated kindness $(P<0.01)$; (3) for the healthcare sector: indifference and awkward social interaction $(P<0.05$; and $(4)$ for partner: being told to conceal and exaggerated kindness $(P<0.05)$. The overall leisure settings and work models produced significant $r^{2}$ values but did not identify specific manifestations predicting psychological distress.

The 10 significant predictors from the setting-specific models were then entered into a final regression model (Table 2), which yielded an $r^{2}$ change of $0.09(P<0.001)$. Four significant predictors emerged: being told to conceal by family $(P<0.01)$, being avoided by family $(P<0.01)$, experiencing exaggerated kindness from family $(P<0.05)$ and awkward social interaction in the healthcare sector $(P<0.05)$.

Table 1. Setting-specific multiple linear regression models predicting psychological distress.

\begin{tabular}{|c|c|c|c|c|c|c|c|c|c|c|c|c|}
\hline & \multicolumn{2}{|c|}{ Friends } & \multicolumn{2}{|c|}{ Family } & \multicolumn{2}{|c|}{ Healthcare } & \multicolumn{2}{|c|}{ Partner } & \multicolumn{2}{|c|}{ Work } & \multicolumn{2}{|c|}{ Leisure } \\
\hline & $\Delta r^{2}$ & $\beta$ & $\Delta r^{2}$ & $\beta$ & $\Delta r^{2}$ & $\beta$ & $\Delta r^{2}$ & $\beta$ & $\Delta r^{2}$ & $\beta$ & $\Delta r^{2}$ & $\beta$ \\
\hline Step 1 & $0.31^{* * *}$ & & $0.31^{* * *}$ & & $0.31^{* * *}$ & & $0.31^{* * *}$ & & $0.31^{* * *}$ & & $0.31^{* * *}$ & \\
\hline Partner & & $-0.14^{* * *}$ & & $-0.14^{* * *}$ & & $-0.14^{* * *}$ & & $-0.14^{* * *}$ & & $-0.14^{* * *}$ & & $-0.14^{* * *}$ \\
\hline Education & & $-0.12^{* * *}$ & & $-0.12^{* * *}$ & & $-0.12^{* * *}$ & & $-0.12^{* * *}$ & & $-0.12^{* * *}$ & & $-0.12^{* * *}$ \\
\hline Health & & $-0.50^{* * *}$ & & $-0.50^{* * *}$ & & $-0.50^{* * *}$ & & $-0.50^{* * *}$ & & $-0.50^{* * *}$ & & $-0.50^{* * *}$ \\
\hline Step 2 & $0.04^{* * *}$ & & $0.07^{* * *}$ & & $0.05^{* * *}$ & & $0.03^{* *}$ & & $0.02^{*}$ & & $0.03^{* *}$ & \\
\hline Told to conceal & & 0.01 & & $0.11^{* * *}$ & & 0.06 & & $0.10^{* *}$ & & 0.00 & & 0.01 \\
\hline Blame & & $0.09^{*}$ & & 0.04 & & 0.02 & & 0.01 & & 0.06 & & 0.04 \\
\hline Increased physical distance & & 0.01 & & -0.03 & & -0.05 & & 0.01 & & -0.03 & & 0.03 \\
\hline Avoidance & & 0.00 & & $0.14^{* *}$ & & 0.02 & & 0.02 & & 0.06 & & 0.04 \\
\hline Excessive hygienic measures & & -0.04 & & -0.05 & & 0.02 & & -0.04 & & 0.04 & & -0.07 \\
\hline Told to disclose & & 0.05 & & 0.06 & & 0.02 & & 0.02 & & 0.00 & & 0.06 \\
\hline Indifference & & 0.01 & & 0.03 & & $0.08^{*}$ & & -0.02 & & 0.00 & & 0.04 \\
\hline Exclusion & & 0.04 & & 0.02 & & 0.06 & & 0.05 & & 0.08 & & 0.05 \\
\hline Awkward social interaction & & $0.10^{*}$ & & 0.04 & & $0.13^{* *}$ & & 0.06 & & 0.02 & & 0.05 \\
\hline Exaggerated kindness & & $0.07^{*}$ & & $0.10^{* *}$ & & 0.04 & & $0.09^{*}$ & & 0.04 & & 0.04 \\
\hline Aggression & & -0.04 & & -0.01 & & -0.02 & & 0.01 & & -0.05 & & -0.04 \\
\hline
\end{tabular}

${ }^{*} P<0.05 ;{ }^{* *} P<0.01 ;{ }^{* * *} P<0.001 . n=601$. 
Table 2. Final multiple regression model predicting psychological distress.

\begin{tabular}{lcc}
\hline & $\Delta r^{2}$ & $\beta$ \\
\hline Step 1 & $0.31^{* * *}$ & \\
Partner & & $-0.14^{* * *}$ \\
Education & $-0.12^{* * *}$ \\
Health & $0.09^{* * *}$ & $-0.50^{* * *}$ \\
Step 2 & & 0.06 \\
Blaming (friends) & 0.05 \\
Awkward social contact (friends) & 0.00 \\
Exaggerated kindness (friends) & $0.09^{* *}$ \\
Told to conceal (family) & $0.10^{* *}$ \\
Avoidance (family) & $0.08^{*}$ \\
Exaggerated kindness (family) & 0.04 \\
Indifference (healthcare) & $0.09^{*}$ \\
Awkward social interaction (healthcare) & 0.06 \\
Told to conceal (partner) & 0.05 \\
Exaggerated kindness (partner) & \\
\hline
\end{tabular}

${ }^{*} P<0.05 ;{ }^{* *} P<0.01 ;{ }^{* * *} P<0.001 . n=601$.

\section{Discussion}

Although previous studies [15-22] have established that HIV-related stigma does indeed independently contribute to psychological distress in PLWHA, the present study is, to our knowledge, the first quantitative study to explore how specific manifestations of HIV-related stigma are associated with psychological distress across a number of social settings. Our findings suggest that certain settingspecific manifestations of stigma are indeed more psychologically damaging than others. Psychological distress was most strongly predicted by three specific manifestations of stigma occurring in family settings avoidance, exaggerated kindness and being told to conceal one's status - and one manifestation in healthcare settings, namely awkward social interaction. Stigmatization by family may be particularly detrimental as families are not chosen and often considered an important source of unconditional love and support. Stigmatization by family may thus threaten a fundamental human need, namely the need to belong [41]. With respect to the impact of awkward social interactions, previous research has shown that many PLWHA assume that health professionals are knowledgeable about HIV and thus expect them to be at ease with them [35]. When health professionals' actions suggest otherwise, disappointment and subsequent psychological distress may ensue.

Our finding that different experiences of stigma impact psychological well being differently depending on the setting in which the stigma occurs has both theoretical and practical implications. First, it suggests that setting and manifestation-specific measures of HIV-related stigma likely provide insight that aggregate measures can not. Second, it points to the importance of gearing stigma reduction interventions to specific manifestations in specific settings. In order to do this effectively, additional research on family and healthcare settings is necessary (for recommendations, see $[11,42]$ ).
Some limitations to this study should be mentioned. First, compared with the general Dutch PLWHA population [43], our study over-represented homosexual men, people with a high level of education and people with a Western background. Although correlational analyses showed no associations between these variables and psychological distress, caution should be applied when generalizing findings. A second limitation is the response rate (RR). We endeavored to increase RRs via personal contact and follow-up reminders, and succeeded in reaching $6 \%$ of all diagnosed PLWHA in the Netherlands. Nonetheless, the potential for nonresponse bias cannot be dismissed. A third limitation is the cultural setting in which the survey occurred. The Netherlands is a fairly tolerant culture. As such, it is possible that Dutch PLWHA experience less stigmatization and psychological damage than PLWHA elsewhere. Although our findings support research on HIV-related stigma and psychological distress conducted in other countries [15-22], we nonetheless recommend replicating our findings in other cultural contexts. A fourth limitation is that this study did not consider the serostatus of interaction partners in settings (e.g. partner, family and friends). We suggest future research control for this. A final limitation is the cross-sectional study design. Although we presumed that stigma impacts psychological well being, one could contend that the direction of the relationship is the opposite. This, however, would require relatively similar bivariate correlations between psychological distress and most of the manifestations of HIV-related stigma in most of the settings. Instead, we found psychological distress to be most strongly associated with very specific manifestations in specific settings. Consequently, we contend that the direction of the relationship assumed is more likely than its alternative.

\section{Conclusion}

This study has uniquely contributed to our understanding of the relationship between HIV-related stigma and psychological distress and added to previous research by demonstrating that it is possible to identify the specific manifestations occurring in specific social settings that are most detrimental to psychological well being.

\section{Acknowledgements}

The authors thank the survey respondents for their participation, the Dutch AIDS Funds and Abbott for their financial contribution (grant number 2006092) and the Dutch HIV Association and the Professional Organization of HIV Consultants (VCHA) for their assistance in the acquisition of data. They also thank Ronald Brands, Iris Shiripinda, Maartje Liebregts, Nicole van Kesteren and Onno de Zwart for their contribution as project committee members. Last, they thank two anonymous reviewers whose comments significantly improved this paper. 
S.E.S. was involved in the design of the study, conducted analyses, interpreted the data and led the writing. J.B.P. also analyzed data, interpreted findings and revised drafts of the manuscript. A.E.R.B. and H.P.S. were responsible for the conception and design of the study. They also assisted with data analyses and interpretation, and reviewed drafts of the manuscript. R.H. and P.M. contributed to the analyses and interpretation of the data as well as manuscript revisions.

There are no conflicts of interest.

\section{References}

1. Bos AE, Kok G, Dijker AJ. Public reactions to people with HIV/ AIDS in The Netherlands. AIDS Educ Prev 2001; 13:219-228.

2. Crocker J, Major B, Steele C, Gilbert DT, Fiske ST, Lindzey G. Social stigma. In: The handbook of social psychology, Vols. 1 and 2 (4th ed.). New York, New York USA: McGraw-Hill; 1998. pp. 504-553.

3. Goffman I. Stigma: notes on the management of spoiled identity.. Eaglewood Cliffs, New Jersey: Prentice-Hall; 1963.

4. Jones EE, Farina A, Hastorf A, Markus H, Miller D, Scott RA. Social stigma: the psychology of marked relationships. New York: W.H. Freeman; 1984.

5. UNAIDS. 2008 Report on the global AIDS epidemic. Geneva: UNAIDS; 2008

6. Chesney MA, Smith AW. Critical delays in HIV testing and care: the potential role of stigma. Am Behav Sci 1999; 42:11621174.

7. Herek GM. AIDS and stigma. Am Behav Sci 1999; 42:11061116.

8. Nyblade L, Pande R, Mathur S, MacQuarrie K, Kidd R. Disentangling HIV and AIDS stigma in Ethiopia, Tanzania and Zambia. Washington, District of Columbia: International Center for Research on Women; 2003.

9. Meiberg $A E$, Bos $A E$, Onya HE, Schaalma HP. Fear of stigmatization as barrier to voluntary HIV counselling and testing in South Africa. East Afr J Public Health 2008; 5:49-54.

10. Vermeer W, Bos AE, Mbwambo J, Kaaya S, Schaalma HP. Social and cognitive variables predicting voluntary HIV counseling and testing among Tanzanian medical students. Patient EduC Couns 2009; 75:135-140.

11. Bos AE, Schaalma HP, Pryor JB. Reducing AIDS-related stigma in developing countries: the importance of theory- and evidence-based interventions. Psychol Health Med 2008; 13:450460.

12. Stutterheim SE, Bos AER, Schaalma HP. HIV-related stigma in the Netherlands.. Maastricht: AIDSFonds \& Maastricht University; 2008.

13. Crandall CS, Coleman R. AIDS-related stigmatization and the disruption of social relationships. / Soc Pers Relationships 1992; 9:163-177.

14. Pryor JB, Reeder GD, Yeadon C, Hesson-McLnnis M. A dualprocess model of reactions to perceived stigma. J Pers SoC Psychol 2004; 87:436-452.

15. Simbayi LC, Kalichman S, Strebel A, Cloete A, Henda N, Mqeketo A. Internalized stigma, discrimination, and depression among men and women living with HIV/AIDS in Cape Town, South Africa. Soc Sci Med 2007; 64:1823-1831.

16. Mak WW, Cheung RY, Law RW, Woo J, Li PC, Chung RW. Examining attribution model of self-stigma on social support and psychological well being among people with HIV+/AIDS. Soc Sci Med 2007; 64:1549-1559.

17. Wu DY, Munoz M, Espiritu B, Zeladita J, Sanchez E, Callacna M, et al. Burden of depression among impoverished HIV-positive women in Peru. / Acquir Immune Defic Syndr 2008; 48:500-504.

18. Clark HJ, Lindner G, Armistead L, Austin BJ. Stigma, disclosure, and psychological functioning among HIV-infected and noninfected African-American women. Women Health 2003; 38:57-71.
19. Kang E, Rapkin BD, Remien RH, Mellins CA, Oh A. Multiple dimensions of HIV stigma and psychological distress among Asians and Pacific Islanders living with HIV illness. AIDS Behav 2005; 9:145-154.

20. Lee RS, Kochman A, Sikkema KJ. Internalized stigma among people living with HIV-AIDS. AIDS Behav 2002; 6:309-319.

21. Riggs SA, Vosvick M, Stallings S. Attachment style, stigma and psychological distress among HIV+ adults. I Health Psychol 2007; 12:922-936.

22. Vanable PA, Carey MP, Blair DC, Littlewood RA. Impact of HIV-related stigma on health behaviors and psychological adjustment among HIV-positive men and women. AIDS Behav 2006; 10:473-482.

23. Bond $V$, Chase E, Aggleton P. Stigma, HIV/AIDS and prevention of mother-to-child transmission in Zambia. Eval Program Plan 2002; 25:347-356.

24. Carr RL, Gramling LF. Stigma: a health barrier for women with HIV/AIDS. I Assoc Nurses AIDS Care 2004; 15:30-39.

25. Gielen AC, McDonnell KA, Burke JG, O'Campo P. Women's lives after an HIV-positive diagnosis: disclosure and violence. Matern Child Health I 2000; 4:111-120.

26. Herek GM, Capitanio JP, Widaman KF. HIV-related stigma and knowledge in the United States: prevalence and trends, 19911999. Am I Public Health 2002; 92:371-377.

27. Malcolm A, Aggleton P, Bronfman M, Galvão J, Mane P, Verral J. HIV-related stigmatization and discrimination: its forms and contexts. Crit Public Health 1998; 8:347-370.

28. Rintamaki LS, Scott AM, Kosenko KA, Jensen RE. Male patient perceptions of HIV stigma in healthcare contexts. AIDS Patient Care STDS 2007; 21:956-969.

29. Sandelowski M, Lambe C, Barroso J. Stigma in HIV-positive women. I Nurs Scholarsh 2004; 36:122-128.

30. Sayles JN, Ryan GW, Silver JS, Sarkisian CA, Cunningham WE. Experiences of social stigma and implications for healthcare among a diverse population of HIV positive adults. J Urban Health 2007; 84:814-828.

31. Swendeman D, Rotheram-Borus MJ, Comulada S, Weiss R, Ramos ME. Predictors of HIV-related stigma among young people living with HIV. Health Psychol 2006; 25:501-509.

32. Varas-Diaz N, Serrano-Garcia I, Toro-Alfonso J. AIDS-related stigma and social interaction: Puerto Ricans living with HIV/ AIDS. Qual Health Res 2005; 15:169-187.

33. Bermingham S, Kippax S. HIV-related discrimination: a survey of New South Wales general practitioners. Aust N Z J Public Health 1998; 22:92-97.

34. Dray-Spira R, Lert F, Marimoutou C, Bouhnik AD, Obadia Y. Socio-economic conditions, health status and employment among persons living with HIV/AIDS in France in 2001. AIDS Care 2003; 15:739-748.

35. Green G, Platt S. Fear and loathing in healthcare settings reported by people with HIV. Sociol Health IIIn 1997; 19: 70-92.

36. Monico SM, Tanga EO, Nuwagaba A, Aggleton P, Tyrer P. Uganda: HIV and AIDS-related discrimination, stigmatization and denial. In: UNAIDS best practice collection. Geneva, Switzerland: UNAIDS; 2001. 31 p.

37. Simoni JM, Mason HR, Marks G. Disclosing HIV status and sexual orientation to employers. AIDS Care 1997; 9:589-599.

38. Berger $B E$, Ferrans $C E$, Lashley FR. Measuring stigma in people with HIV: psychometric assessment of the HIV stigma scale. Res Nurs Health 2001; 24:518-529.

39. Kalichman SC, Simbayi LC, Jooste S, Toefy Y, Cain D, Cherry C, Kagee A. Development of a brief scale to measure AIDS-related stigma in South Africa. AIDS Behav 2005; 9:135-143.

40. Veit CT, Ware JE. The structure of psychological distress and well being in general populations. / Consult Clin Psychol 1983; 51:730-742.

41. Baumeister RF, Leary MR, Higgins ET, Kruglanski AW. The need to belong: desire for interpersonal attachments as a fundamental human motivation. In: Motivational science: social and personality perspectives. New York, New York, USA: Psychology Press; 2000. pp. 24-49.

42. Brown L, Macintyre K, Trujillo L. Interventions to reduce HIV/ AIDS stigma: what have we learned? AIDS Educ Prev 2003; 15:49-69.

43. HIV Monitoring Foundation. Monitoring of human immunodeficiency virus (HIV) infection in the Netherlands. Amsterdam: HIV Monitoring Foundation; 2008. 